\title{
What If Social Science Methods Had No Homeland?
}

Detour via a Sociohistory of the Chinese State through Its Archives Issues in Social Science Debate in Xi Jinping's China

\section{Aurélien Boucher}

\section{CpenEdition}

\section{Journals}

Electronic version

URL: http://journals.openedition.org/chinaperspectives/8377

DOI: 10.4000/chinaperspectives.8377

ISSN: 1996-4617

\section{Publisher}

Centre d'étude français sur la Chine contemporaine

Printed version

Date of publication: 31 December 2018

Number of pages: 11-19

ISSN: 2070-3449

\section{Electronic reference}

Aurélien Boucher, «What If Social Science Methods Had No Homeland? », China Perspectives [Online], 2018-4 | 2018, Online since 31 December 2019, connection on 24 March 2020. URL : http:// journals.openedition.org/chinaperspectives/8377; DOI : https://doi.org/10.4000/chinaperspectives. 8377 


\title{
What If Social Science Methods
}

\section{Had No Homeland?}

\author{
Detour via a Sociohistory of the Chinese State through Its Archives
}

\author{
AURÉLIEN BOUCHER
}

\begin{abstract}
This article studies the methods used by Chinese and foreign social science researchers in their analysis of the contents of the state and Party administration archives of the People's Republic of China. Through the study of this particular subject, I demonstrate that the "tactics" used in the study of contemporary Chinese society may also be found in the study of totalitarian societies and to a lesser extent, in the study of modern bureaucracies. This detour via the method leads us to reconsider the question of the need for a "Sinicisation of the social sciences." More specifically, I call into question the idea that the heuristic nature of a method is necessarily adversely affected once past the frontier.
\end{abstract}

KEYWORDS: social science, Sinicisation, methods, archives.

\section{Introduction}

T he project that consists of Sinicising the social sciences (zhongguohua de shehui kexue 中国化的社会科学), in particular sociology, has been a recurring theme for almost a century. Indeed, since the introduction of the social sciences in the late nineteenth century, certain Chinese intellectuals have wanted to "transform Chinese society in order to 'save the country' and build a modern nation in the face of the threat from western powers" (Merle 2007: 31). From then on, they have never ceased to question the validity of the methods and approaches developed in so-called "Western" fields. The famous work by Fei Xiaotong 费孝通, From the Soil (xiangtu zhongguo 乡土中国), published in 1948, sets itself the objective of identifying the ideal-typical characteristics of China through a systematic comparison with a supposedly "modern" and "urban" West as early as 1932 Sociologist Sun Benwen 孙本文 had already formulated the idea of creating a Sinicised social science. He wrote that (Li and Cao 2013: 3):

Using methods imported from the United States and Europe and taking as a starting-point the theoretical minutiae of European and American scientists to develop a specifically Chinese ideology and societal system, then following this with a practical analysis based on the realities of the entire country and combining it all to establish a Sinicised sociology, is a task that is urgently needed.

Since this statement was published, many debates have been held on the subject, in particular in the 1980s and 90s, when Chinese historians, sociologists, and anthropologists were able to expand theoretical and methodological horizons that since 1957 had been limited to those of Marxism (Wang 2017: 15). Moreover, these debates, which have taken many a conceptual turn (localisation, Sinicisation, de-Westernisation, and post-Westernisation), are not specific to China but are reminiscent of those held on the study of so-called post-colonial societies. Indeed, in the opinion of cer- tain authors citing the route traced by Saïd (2003), the "Sinicisation of the Chinese social sciences" and even the birth of a "post-Western sociology" would be justified by the fact that Chinese social science researchers are considered to have suffered an "epistemic injustice" (Roulleau-Berger 2016). (1) Moreover, to paraphrase Jean-François Bayart, the debate on the Sinicisation of the social sciences has become an "academic carnival" (Bayart 2010) in the sense that it has given rise to the adoption of contradictory and disorganised positions.

For example, Sun Benwen 孙本文 advocated using methods developed in Europe and the United States whilst others such as Shi Ying 石英 (2) defended the idea that the heuristic value of these methods was weak when applied to China. More specifically, Shi Ying claimed that "French and American sociology" (3) traditionally favoured quantitative methods whose use was especially limited in China (Shi 2013: 102-3). Since I remain unconvinced by the idea that Emile Durkheim (given as an example by ShiYing) persistently used a quantitative method in his studies on the elementary forms of religious life (Durkheim 2013a) or on the division of labour in society (Durkheim 2013b), and have not observed that the sociologists of the Chicago School (Chapoulie 2001) actually fell into a quantitative bias, this article intends to revisit the supposedly national specificities of the analytical methods used in the social sciences.

More precisely, I will examine the extent to which the methods used by social science researchers in their efforts to understand contemporary Chinese society in terms of social history and the sociology of the state are different from and/or resemble those used in the study of other societies.

1. The use of the conditional here is appropriate to the extent that as in the case of "post-colonial studies," the question of "epistemic injustice" has been called into question. The latest critique to date has been published in the review Theory, Culture and Society, https://www.theoryculturesociety.org/review-of-laurence-roulleau-berger-post-western-revolution-in-sociology/ (accessed on 21 August 2018).

2. Shi Ying is deputy director of the Shaanxi Academy of Social Sciences.

3. I am using the terms "French and American sociology" here in order to reproduce the author's style more accurately. I would like to apologise and absolve myself from this inappropriate objectification. 
Indeed, if we accept the postulate that the social sciences, whether Sinicised or not, are based on the production of assertions concerning the social world produced by means of a theoretical grid of intelligibility, empirical observations, and rational arguments converging towards a thesis (Passeron 1991: 35), then analytical methods constitute a subject of study that allows us to understand the possible need for the "de-Westernisation" (RoulleauBerger 2011) of social sciences. Since I cannot, in just one article, deal with the question of concepts, discursive rationality, and methods, I hereby propose to question the heuristic value of a Chinese reconstruction of the social sciences based on the particular case of the methods used to analyse the archives of the government and Party in mainland China. In other words, my article aims to discuss the extent to which the methods used to understand Chinese society through a study of its archives are sufficiently "unique" to justify the Sinicisation of the social sciences and the rejection of methods used elsewhere.

In the present case, therefore, it will be a question of listing and analysing the logical procedures by which social science researchers, in their study of the state in contemporary China, transform the textual content of official documents into scientific assertions, and at the same time to ask ourselves whether or not these procedures are to be found in other fields.

To do so, I will analyse a set of research papers that deal with public policies and cover a relatively wide range of subjects ranging from the Great Famine (Dikötter 2010;Yang 2012) to the provincial purges of 1956 (Forster 1999; Teiwes 1966). To a lesser extent, I will use my own research work on reforms in the management of the sporting elites (Boucher 2017). This choice, which is necessarily arbitrary and incomplete if we accept the epistemological postulate that the social sciences researcher cannot cover all the social facts and points of view of those concerned, has been guided by two constraints: firstly, my limited knowledge of the work of the increasing number of colleagues using the government and Party "archives" in their work on the sociology of the state (Kraus 2016), and secondly, the limited number of publications analysed-too few according to Jean-Luc Domenach (2004: 87) -in which the researchers have revealed their analytical methods, doubts, hesitations, and limits.

By taking this limited body of work as our starting point, yet including researchers from different geographical horizons, I intend to demonstrate that archive practices in the "contemporary China field" possess several specific nuances in the sense that certain methods are used to a greater or lesser extent than others but that these methods can also be found elsewhere.

To do this, this article has been organised into three sections. In the first, I will reveal the tactics used in China to escape the trap of "State ethnocentrism" (Spire 2006), that is to say, the methods used in order not to produce a narrative limited to a reproduction of pensée d'État (Bourdieu 1994: 101). This section will support the idea that these methods are useful for a study of all forms of bureaucracy as understood by Max Weber. Secondly, I will analyse how "playing with scale," that is to say, the comparison of local archives with national directives, has allowed us to refine our understanding of power structures in a totalitarian society in China and in the USSR. The final section aims to show that the tendency of Sinologists to analyse semantic conflicts in order to present the official ideology as an indicator of conflicts between factions existed at an earlier stage in studies on the USSR when researchers came up against the same problem of access to the archives, and therefore does not constitute a "Chinese particularity" (Zhongguo tese 中国特色).
By means of this analysis, I would ultimately like to put an end to a false debate, certainly more ideological than productive, by demonstrating that the methods developed or refined by any given researcher are simply intended to be reused anywhere they may favour the emergence of a scientifically justified assertion and do not depend on "national identity."

\section{A debate in the field of social sciences}

Certain epistemological considerations lead us to situate this debate in a wider context than that of sociology alone and to extend the discussion to the social sciences as a whole. Like Passeron, I think that history, sociology, and anthropology are situated in the same logical area, that is to say, obeying the same "set of constraints that define the meaning of what the fact of an assertion being true or false signifies" (Passeron 1991: 617).

Contrary to the logico-mathematical sciences, for which abstract reasoning is sufficient in itself, and contrary to the physico-experimental sciences that seek to model natural phenomena, often at a price of approximations, where the social sciences are concerned, whether it be a question of history, sociology, anthropology, or even economics, it is scarcely possible to "prove" a thesis without recourse to empirical observations. Another particularity of the social sciences lies in the fact that it is not possible to define a "social law" based on the reproduction of an experiment where a single parameter has been isolated, as a chemist or physicist might do in the laboratory.

Social science researchers must therefore base their reasoning on cases for which they have analysed the historic circumstances and compared relevant features, whereas the physicist or mathematician does not have to worry about temporal aspects and the degree to which assertions are generalities (or to a lesser extent once the frame of reference has been defined). The fact that history, sociology, and anthropology belong to the same assertoric space has nonetheless several advantages: what is true in one branch of the social sciences must be validated in another and perhaps invalidated in another, to the extent that all these "branches" share (and use to a greater or lesser extent) their methods, discursive rationalities, and paradigms.

As a result, this present study of the methods used in the analysis of the archives calls for a "social sciences" generalisation that is independent of the disciplinary field of the researchers and research under study. Moreover, certain of the latter may well be socio-historians or historians constructing their assertions with the help of concepts issuing from "sociologists" or "political science" specialists.

\section{Tactics to escape the trap of state ethnocentricity}

The social science researcher, whether a specialist in migration, agricultural, cultural, educational, or sports policy, historian or sociologist, tends, when dealing with a "modern state" (Genet 1997), to understand public policy through the laws, directives, debates between political leaders, internal reports, and circulars issued by the various government departments. These archives, which often cannot be consulted before a certain time has elapsed and sometimes bear the "state 
secret" seal (Laurent 2003), are virtually essential for the study of certain subjects.

This tendency to rely on state archives (or those of the party-state) is all the more marked when the state is defined as an institution that aims to have a "legitimate monopoly over physical and symbolic violence" (Bourdieu 2012: 14). Seen in this light, the state can only exist if a "constituted authority" sets out to implement, measure, evaluate, and record the extent to which "the cosmos of abstract rules" (Weber 1995: 294) established by political leaders tends to transform social affairs. As soon as a more or less coordinated action by agents of the state and acting in the name of the state takes place, it will always be accompanied, in a modern state, by the production of rules, barometers, standards, and reports intended to ensure the rationalisation, and consequently the success, of the public policy in question.

Whether we find ourselves in a "totalitarian" situation where, as Hannah Arendt has underlined, the selection of party-state agents depends on their loyalty to the regime (Arendt 1985: 323), or in a modern democracy similar to the "pure type of legal domination" (Weber 1995: 294-301), we will always find groups organised in the name of the state (or party-state) not only to exercise their authority over the living, but also to count the dead. So whether we are seeking to establish the effect of the one-child policy on the birth rate (Attané 2011), the Great Leap Forward on mortality (Cao 2005), or that of the act legalising abortion in France (Bajos, Moreau, Leridon, and Ferrand 2004), it would seem difficult to proceed without consulting the archives.

In every case, the researcher will inevitably face varying degrees of precision in the data produced by the state department. Estimations are all the more difficult, since all the data is "sensitive" and has been gathered by civil servants who have been trained to a greater or lesser degree in the collection and compilation of data (Ghosh 2014). Notwithstanding the imperfections of this data, it would be impossible to ignore it. Even where there exist associations in civil society or international organisations such as the World Health Organisation that are able to offer alternative points of view, state data, which is based like any other data on arbitrary categories and constructions, cannot be ignored.

Whenever we deal with state data we run the risk of being locked into "state ethnocentrism." Indeed, as Pierre Bourdieu reminds us, it is sometimes difficult to extricate ourselves from the categories of perception and classification that the state imparts through use of its monopoly over legitimate symbolic violence (Bourdieu 2012: 14). In the case of China, certain researchers have clearly had difficulty extricating themselves from categories such as "new China" (xin Zhongguo 新中国), "three years of natural disasters" (sannian ziran zaihai 三年自然灾害), and "unnatural deaths" (fei zhengchang siwang 非正常死亡), and substituting more stenographic categories as understood by Passeron (2006: 113) — that is to say, better able to describe the social organisation, period, or phenomenon under observation. Breaking free from state ethnocentrism also consists in not having blind confidence in public statistics, but in "deconstructing" them historically, that is to say, revealing the political stakes and bureaucratic action that shaped them. In other words, such a rupture necessarily involves a "constructivist" approach that has nothing to do with the subject or state under study. More precisely, it is an imperative each time it is impossible to reduce the bureaucratic field to a Hegelian vision that reifies the field as a "universe in which the social agents have no personal interest and sacrifice their own interests to the public, public service, and the universal" (Bourdieu 1994:
161). In this type of approach, the work may also consist of understanding state data by carrying out a socio-analysis of its producers (how the latter are selected, promoted, and punished), who by their own values and/or interests are likely to influence the way in which public data is constituted. In the case of an analysis of the archives of the People's Republic of China, the need to deconstruct the official discourse is all the more evident since all the historian has at his disposal is government and Party data, the direct or indirect access to which remains relatively unpredictable (Thøgersen 2006: 190). Indeed, in the case of the study of the Great Famine, although the use of oral memory allows it to be put into narrative form more effectively, given the size of the country and the variety of local situations, it is of no help in estimating the number of victims. A second difficulty, also found in the study of the great famines in the USSR and Ukraine (Davis 2009), is that no organisation independent of the power of the party-state was able to carry out a methodical census on a national scale. Lastly, the historian must deal with archives that are not easily accessible and have not been sorted, preserved, and made available in a homogeneous fashion (Moss 1982; Moseley 1987) within a well-defined, rational, and legal framework (Boucher 2017: 143).

There is no doubt that these oft-mentioned problems exist, yet rare are the archive extracts concerning "materials from the history of the Party" (dangshi ziliao 党史资料), "documents on culture and history" (wenshi ziliao 文史资料), or memoires of former leaders, where social sciences researchers, irrespective of country, have given us a glimpse into the logical operations by which they transformed the semantic content of a document into a scientific assertion.

The Great Famine is one of the rare subjects for which historians more or less systematically endeavoured to question the way in which the archives had been compiled and the accounting statements contained in government and party documents. The irony of this situation lies in the fact that the methods and precautions taken by the researchers were debated and discussed far more when they realised the difficulties inherent in the estimates (Yang 2013; Dikötter 2010; Cao 2005: 2-9). Their postulates and analytical methods were also more detailed when they were faced with opinions such as those of Sun Jingsheng 孙经生 (2011) that went so far as to deny the political (and therefore unnatural) character of the deaths. These debates also revealed tactics that would only have been divulged very partially in other circumstances.

In order to give an account of the sensitive and uncertain nature of the level of cereal production during the Great Leap Forward, Frank Dikötter used the tactic of comparing the data compiled by the Grain Office with that of the statistics, concluding that "if the leaders were themselves lost in a morass of statistical invention, it seems unlikely that we can magically extract the numerical truth from a single document in the Party archives" (Dikötter 2010: 130). In making this comparison, Dikötter has revealed a stratagem that consists of comparing the assessments of a social phenomenon made by rival institutions.

This stratagem was not, moreover, restricted to Frank Dikötter.Yang Jisheng 杨继绳, another specialist of the Great Famine, proceeded, like his Dutch colleague, to carry out a detailed review of the existing estimates and their sources. From the same critical angle, he compared the data from the National Bureau of Statistics, which were themselves transmitted by the National Security Bureau, with the figures published at the provincial level.

This tactic, particularly useful in his case for assessing the extent of statistical invention, scarcely allows the order of magnitude to be stated to 
any significant degree. Moreover, it is only applicable to this case to the extent that the subject under study was "scrutinised" by agents sufficiently independent from each another and relatively ignorant of each other's practices. Indeed, in other circumstances, it is always possible that civil servants attached to separate entities reach agreement on the nature of their diagnosis with the aim of producing a result acceptable to all, that is to say, protecting the interests (even the life) of all the protagonists. In certain cases, it is also possible that one administrative department alone has preserved the trace of an "event" such as the results of a local sporting competition. Therefore, a comparison of public statistics issued by different administrative levels and authorities, which in certain cases would enable the extent of statistical invention to be traced, is not always fruitful.

It is a fair bet that in the case of so-called "socialist" societies, there is probably less chance that a comparison of published public data by different authorities proves unequivocal. Indeed, the duplication of government institutions with institutions linked to the Party, commissions (weiyuanhui 委员会) responsible for administrative work, and multiple bureaux (ju 局) means that one servant of the party-state's field of action often encroaches on that of another. This type configuration that Hannah Arendt identifies as one of the characteristic traits of totalitarian systems (Arendt 1985: 413) works, in a sense, in favour of the researchers.

To continue with the case of the Great Famine, many debates focus on the question of the number of deaths, which shows that in mainland China, as in the USSR, an impossible compromise existed between statistics and revolution (Mespoulet 2001, 2003, 2008). Although almost all researchers have relative confidence in the "figures" published in the local and national archives, their conclusions still vary as to the magnitude of the disaster. Whilst Frank Dikötter, quoting Chen Yizi 陈一咨, cites a minimum of 45 million premature deaths caused by mandatory collectivisation (Dikötter 2010: 325), the most fervent defenders of Mao's heritage, such as Li Shenming, cite only 2.5 million deaths, of which only a minority were due to the famine (Yang 2013: 75). For his part, Yang Jisheng prefers to refer to the assertions of Wang Weizhi 王维志 (Yang 2012: Chapter 11), who was able to carry out inspections in the provinces in the early 1960s for the Ministry of Public Security before drawing up his own estimates. To the 33 to 35 million "unnatural deaths" reported by Wang Weizhi, Yang Jisheng, like Cao Shuji 曹树 基 (Cao 2005: 7), adds the "unnatural deaths" from the years 1958 and 1962 (Yang 2012: Chapter 11), thereby once again escaping the trap of state ethnocentrism that limits the Great Famine to an "official" period of three years even though local circumstances affected the length and extent of the phenomenon.

Whatever estimates were put forward, the debates, which were sometimes stormy, at least had the advantage of forcing the researchers into more detailed justification (Yang 2013: 75-81). The first section of Cao Shuji's book, entitled Documents and Methods, like the articles on the subject published in the journal Yanhuang chunqiu 炎黄春秋 before it was taken over by the political authorities, contains many fertile analytical considerations that could be used in the study of other subjects. For example, the article by Chun Shihua 淳世华 (Chun 2014: 30-8), based on the study of Pengshui county, reveals particularly well how cadres in the People's Communes invented sub-categories of "unnatural deaths" in order to minimise the number of deaths due to the Famine. In Pengshui, where the death rate, according to the same sources, fell from $11.77 \%$ in $1955-1957$ to $9.18 \%$ in 1961 , up to $85 \%$ of unnatural deaths were attributed to pulmonary embolism, although this condition was closely linked to the alimentary and sanitary situation. In addition, Chun Shihua, who himself lived through this period, notes that many older people who died of hunger were placed in the "died of old age" category. Although this aspect did not escape other historians (Dikötter 2010:274), it was reproduced in this article in great detail thanks to the cross-referencing of reports on individual cases, macroscopic enumeration, and by placing the number of deaths and their causes in a historic perspective. Lastly, Chun Shihua was in a better position to deconstruct these categories because he had himself been present at the events. His deconstruction of the state's categories was therefore based on what the French sociologist Gildas Loirand called the "a posteriori sociologisation of an indigenous experience" (Loirand 2006: 629). In other words, Chun Shihua marshalled his own memories dating from a time when he ignored socio-historical research, in order to assess the veracity of official accounts.

\section{The need to play with scale}

Therefore, studies on the Great Famine are also a good example of the need to vary the point of focus and of the necessity for a comparison of national and local data and individual memories.

As May Bo Ching points out, from the late 1980s onwards, "playing with scale," as the historian Jacques Revel (1996) calls it, became common amongst Chinese historians. Like other members of the community of historians, Chinese researchers realised that a local approach "allowed them to measure the impact of the State at local level more accurately" (Ching 2017: 32).

"Playing with scale," which is not specific to China, seems to have been particularly productive in the study of so-called "socialist" societies, notably since it permits a more nuanced account of the role of ideology and the exercise of violence in producing obedience, and in particular, reveals the initiatives of local cadres that sometimes limited the scope of political campaigns and brought to light, at a risk to their own lives, statistics that were not consistent with the Plan. In other words, it would seem that, as with studies on the formerly socialist countries of Eastern Europe, Sinologists, independent of their nationality, have gradually refined the theoretical intelligibility framework of totalitarianism that was challenged in particular by Kershaw (Kershaw and Moshe 1997) through recourse to the archives and traditional methods of social history (Preziosio 2008: 21).

Like their opposite numbers working on East Germany, Sinologists have been led to take "peripheral power" (Rowell 2002: 102) into greater consideration. Although Hannah Arendt's observation that totalitarian systems are based on a two-tier system assured by the "political movement" and an administration that is subject to it has not been challenged, China specialists are no longer satisfied with seeing the members of the Party as a "transmission belt" between the supreme leader and the masses, whose obedience is guaranteed by the shapelessness in the political regime, ignorance of the labyrinthine circuits of transmission, and fear of charivaris (Arendt 1985: 408-9). Gaining access to the local archives (districts, municipalities, provinces) of the Party and government has enabled researchers to take a fresh look at centre-peripheral relations, highlighting the work of presenting policies issued from the centre.

Keith Forster's work on the provincial purges of 1957-1958 provides an excellent example of how a local approach using archives enables the researcher to refine, or even invalidate. This is a textbook case where, as the author himself claims, new empirical materials lead the researcher to review 
theories constructed from a "top-down" approach, that is to say solely from an analysis of declarations made by central authorities and other extracts from the press that reached Hong Kong. In the case of the 1957-1958 purges, Frederick Teiwes's work, which previously represented a benchmark, presented the 1957 purges as "a means of forming loyal local branches (of the Party) to lead the Great Leap Forward" (Teiwes 1966: 32). Keith Forster's study, based on more varied data, namely the internal archives of the Party and biographies of the main players in the purges, led to a quite different version. More precisely, in the case of Zhejiang, it showed that "the provincial purge was not so much a preventive measure although it contained several elements of this, but rather the result of an explosion of accumulated tensions" between cadres from the local area at the head of the Party, and those faithful to a protégé of Tan Zhenlin 谭震林 (4) (Forster 1999: loc 5005). The study demonstrates that political campaigns, even during the Mao years, cannot be seen solely as the product of a totalitarian system where regular purges were the only means of keeping the "movement" alive and ensuring continuing loyalty to the supreme leader.

It is quite remarkable to note that by following a similar method, the heirs of Moshe Lewin and Sheila Fitzpatrick arrived at relatively similar conclusions on the subject of the great purges in the USSR (Mc Dermott 2004: 6). Although the conclusions of Sovietologists such as Getty who are considered "revisionist" do not question the importance of the role played by Stalin in triggering the purges, they also see them as the extension of "structural and factionist conflicts within the Party machine" (Getty 1985: 7). Playing with scale based on archival data therefore offers an alternative vision to the explanation of psychological disturbances suffered by the supreme leader and the "totalinarianizing pretentions of the totalitarian paradigm" (Fitzpatrick 1986: 58). This new approach therefore provides a better explanation of variations in the magnitude of the purges at local level and of the more or less active mechanisms of support for central policies on the part of local cadres. As such, this approach, and the methods resulting from it, cannot be seen as having a use that is specific to China or being of Chinese origin, but rather as particularly appropriate tools for a researcher who wishes to study a public policy intended to have a universal application through the intermediary of a segmented bureaucratic organisation whose members have vested interests.

\section{Analysing political conflicts through semantic conflicts}

Up until now, our analysis of methods of interpreting government and Party archives has relied mainly on research subjects for which it has been possible to "exhume" a relatively extensive mass of documents from the archives. For example, in a country where the migration of populations was strictly controlled, it was relatively easy for the regime to produce a large amount of data on the population at every administrative level. Consequently, the volume of useful documentation in a study of the Great Famine is potentially large (Ma and Xing 2008: 372-85).

On the other hand, for the study of subjects such as sport, especially before the relative opening up of the documentary resources of the contemporary period, social science researchers do not always have a meaningful volume of documentation at their disposal. Moreover, certain events such as the Cultural Revolution possess the dual inconvenience of being still very sensitive and of having led to the destruction of a great number of documents, and even of the authorities responsible for preserving them. For this type of subject, access to primary sources is from the outset far more delicate, or even impossible. Even Yang Jisheng, who had access to many firsthand documents when writing his work on the Great Famine, was obliged to rely more on secondary source documents borrowed from the official historiography to write his work on the Cultural Revolution (Yang 2016).

This propensity to use secondary source archives is therefore not restricted to the author. In the present case, it would seem to be linked to the subject under study. Therefore, whether the researcher is working on China or on another geographical area, whether he/she is Chinese or not, certain subjects such as "political campaigns" lead to confirmation of the saying that "the field dictates its own law" (Beaud and Weber 2003: 56); that is to say, it imposes on the researcher methods and detours, stages necessary to the scientific construction of the subject. Indeed, the tactics used to get the best out of the rare archives available very often remain the same whether the author is a retired member of the Xinhua News Agency (Yang Jisheng), a specialist in twentieth century China teaching at Harvard (MacFarquhar), or a career diplomat posted in China during the Cultural Revolution (Simon Leys). In all three cases, the absence of access to debates, minutes of meetings, notes, private diaries, and other diaries by close collaborators of the leaders cannot be replaced. The researcher is condemned to rely on an indepth reading of declarations, circulars, and other propaganda, and then to detect in the semantic conflicts and other allegories (MacFarquhar and Schoenhals 2006: loc 628) traces of power struggles that can also be verified through the eviction of Comrade So-and-So from the benches of an official tribune.

For example, Roderick MacFarquhar traces the intention of Mao Zedong to trigger the purge of Liu Shaoqi 刘少奇 and Deng Xiaoping 邓小平 back to the dissent that arose during the meeting on socialist education held at the end of 1964 (Mao was initially excluded from the conference). To defend his argument, he maintains that the directive stating that "amongst [the leaders] at the highest levels, there are some people in the communes, districts, counties [xian 县], special districts, and even in the work of provincial and Central Committee departments, who oppose socialism" (MacFarquhar and Schoenhals 2006: loc 244), displays the premises of the purge to come, and that this was linked to critiques of collectivisation.

Using a similar approach, Simon Leys, in The Chairman's New Clothes, clearly explains the type of methodological postulates on which he based his analysis of the libretto for the opera Hai Rui Dismissed from Office as being a plea for the rehabilitation of Peng Dehuai 彭德懷 and an attack against "the person and style of Mao." He mentions the fact that this "recourse to historic apologia to criticise the present is a Chinese tradition as old as historiography itself. Commentators in ancient China were already interpreting the Annals of Spring and Autumn, attributed to Confucius, as a coded language, each word of which hid scathing judgements of moral politics (...)" (Leys 1998: 33).

Although we may doubt, in referring to the manner in which the Greeks used their myths to settle their political quarrels (Veyne 1983: 89-104), that this is a procedure unique to Chinese civilisation, the case of Hai Rui Dismissed from Office raises the question of forms of criticism under a regime of "real socialism" (Lew 2002). To the extent that any "deviant" line (or "deviationist" to use the accepted term) constitutes a threat to the charismatic

4. Tan Zhenlin was a senior cadre in the Party, member of the Seventh Central Committee and deputy secretary general of the Central Committee from 1954 (Zhonggong Zhongyang fu mishuzhang 中共中央副秘书长). Above all, he was previously governor of Zhejiang, which explains the presence of his loyal followers in the ranks of the senior cadres of the province. 


\section{Difficulties in interpreting archives in the fieldwork of sport}

I have personally been confronted with the impersonal nature of the archives in my own fieldwork, notably when I sought to retrace the development of policies relating to the training of sporting elites at the beginning of the period dubbed "Reform and Opening." I was attempting to understand how the purges of the Cultural Revolution had resulted in the setting up of a new "revolutionary sports commission" whose motto was "friendship first, competition after," and how the transition to a policy, the aim of which was to make China the leading Olympic power, operated.

Since I am neither Chinese nor a member of the Chinese Communist Party, I was excluded from accessing the personal notes and biographical elements of senior leaders of the National Sports Commission. In other words, like many other researchers working on the history of the "First People's Republic of China" but not sworn in by the Party, I was not able to base my assertions on primary sources in order to back up my hypotheses. Perhaps I could have... but I preferred not to naively attempt to try to procure them, since such a request might be doomed to failure, and above all, a potential source of trouble.

The local archives to which I had access thanks to the generous help of Chinese colleagues contained hardly any documents relating to the period 1966-1968, which seemed the most "sensitive," since it was not spared its share of public denunciations and suicides. ${ }^{(5)}$ In the local archives of the sports commissions, I was unable to find a document relating to the dismissal or replacement of a cadre, trainer, or athlete. Like my predecessors, I was also led to concentrate on the Party's summary of local history and a thorough lexical analysis of the available national directives. In an article published in Histoire Sociale (Social History) (Boucher 2017), I explain how I compared the archives of the various administrative levels in order to measure the resistance encountered.

However, that article did not mention another aspect of my research, which was carried out using secondary sources, since my analysis was also completed by the use of notes from meetings, speeches, and other documents mentioned in the biographies of $\mathrm{He}$ Long 贺龙 (Liu 2007), Rong Gaotang 荣高棠 (Li 2002), Wang Meng (Wang 2008), Xu Yinsheng 徐寅生 (1995), Zhuang Zedong 庄则栋 (Guan 1986), and Rong Guotuan 容国团 (He 2009).

I tried to contact the publishers and authors of some of these biographies in an effort to establish the conditions under which they were produced (official commission, access to the archives?) in order to be able to use these secondary sources more productively. It was a laborious initiative and met with success in only one case: the biography of Rong Guotuan. those that rained down on Peng Dehuai, the Hai Rui of Lushan, must also be approached with caution, since once a "class enemy" has been identified, it becomes particularly dangerous to diverge from the criticisms heaped upon the unfortunate recipient.

This is, in any case, a set of precautions that specialists in the archives of the political policies of Eastern Europe learnt to take, as in the case of the Czech writer Milan Kundera. The latter was forced to denounce an intelligence officer named Miroslav Dvoracek who was working for the Americans, since he knew that Dvoracek had already been denounced and that he would be in great danger if he did not follow suit (Peto 2009: 276). For the same reasons, "directives," "announcements," and "reports," statements that can be collected on less sensitive subjects, are generally very evasive and impersonal. They scarcely allow, especially in a situation that turned a decision into unanimous thought, retracing the divergent debates and opinions emitted, and above all stifled, that existed before the administrative act was made public.

This approach, which tends to make discourse analysis a key to understanding political struggles, is therefore dependent on the conditions under which the historian (non-affiliated to the Party) is working. The conditions described and the methodological approach they lead to are nonetheless not specific to the People's Republic of China. Indeed, USSR specialists also had recourse to this type of method, in particular before what they term the "archive revolution" (Raleigh 2002; Kragh and Hedlund 2015).

In his pioneering work on the great USSR purges published in the 1970s, Robert McNeal relies almost exclusively on the official decisions of the Communist Party of the Soviet Union in order to highlight the conflicts and divergent points of view amongst those close to Stalin (McNeal 1971: 17785). Like Keith Forster, he also used local and national sources in order to understand the logic of the purges. On the other hand, unlike Keith Forster, he was able to consult a collection of documents from the regions on the western periphery of the Eastern bloc (the Smolensk Archive), part of which was already available for consultation in the 1980s. Like MacFarquhar (who had worked on the origins of the Cultural Revolution), Robert McNeal undertook an in-depth analysis of the content of the "letter of 13 May 1935," which marked the beginning of the purges. This letter, requiring the "verification" of Party members' cards, allowed him to show that in the initial stages of the purges, the "targets" had certainly not yet been clearly identified (Getty 1985: 63), which seems very different from the Chinese case.

The comparison between these two situations is therefore particularly instructive in that it shows that even when the methodology is relatively similar, and used in the study of relatively comparable subjects, it can lead to completely different conclusions. In applying virtually similar methods to the subject of the "purges" in the USSR and China, we end up exemplifying the "recidivist" thesis so dear to Lucien Bianco (2014), demonstrating that the "purges" made necessary by the very nature of the two regimes followed their own particular dynamics.

\section{Conclusion}

Following this summary of the methods used to interpret government and Party archives in mainland China, I hope to have demonstrated that the methods of interpreting the archives of the People's Republic of China possess a few specific features due to the constraints of the Chinese con-

5. Notably those of Fu Qifang, Jiang Yongning, and Rong Guotuan, all former players in the Chinese table tennis team and trainers of the national team. 
text, yet are nonetheless not substantially different from those used elsewhere.

Whether we are considering the tactics used to deconstruct/reconstruct public statistics and pensée d'État along post-Kantian "constructivist" lines, in terms of the methods harnessed in order to understand "bureaucratic stratagems," or the paths followed to retrace the chain of political decisionmaking, nothing would seem to require a specifically Chinese social science, that is to say a discipline relying on methods of producing evidence and an interpretive framework that are uniquely valid in China. With regard to the analysis of the archives, the few recurring methods identified here (synchronous and diachronic comparisons of the public statistics published by separate institutions, sociohistory of the conditions under which state data is produced, a posteriori sociologisation of indigenous experiences, playing with scale, and the analysis of semantic conflict as disguised political conflict) possess nothing that is specific to mainland China and a fortiori to the study of the famous " 5,000 years of history of Chinese civilisation," a product of propaganda (Ge 2014).

In this article, I have paid special attention to putting into perspective the methods used by USSR, East Germany, and mainland China specialists. In all three cases, the dual party-state structure and the political regime constitute traits that are relevant enough to justify the use of similar methods. However, as I have pointed out, certain methods used with the aim of overcoming the trap of "pensée d'État" have travelled beyond the frontiers of socialist countries. More specifically, these methods procure an effect of knowledge each time one encounters a bureaucracy constituted in order to exercise a legal rational authority. From this perspective, I therefore conclude that a method is ultimately simply an instrument in the service of a demonstration that is not intended to have a particular homeland. In other words, this study of methods, fragmentary though it may be, encourages us to defend the idea that in the social sciences, the validity of a method can only gain legitimacy by reference to its heuristic or stenographic value and is not ordained_or imagined —on the basis of its national identity.

More broadly, therefore, this conclusion encourages us to doubt the idea that the invention of a Sinicised social science, whatever its subject might be, is sine qua non for the production of knowledge regarding Chinese society. This postulate, which has a strong odour of nationalism about it, feigns to ignore that Chinese and foreign researchers already share many concepts and methods to the point where it sometimes becomes hazardous to determine the "national identity" of the said methods or concepts (Boucher 2018).

Moreover, the postulate of the need for a Sinicisation of the social sciences represents an additional threat to the empowerment of the academic field over its own purpose of "knowledge for knowledge's sake" by introducing nationality as a new standard of scientific legitimacy (in place of the heuristic nature of the assertions produced). Although the term "threat" might certainly seem excessive, we would like to mention the ravages caused by French and German chauvinism in the development of the sciences at the beginning of the twentieth century (Reinbothe 2010), and also how previous attempts at the promotion of national sciences such as qigong (Palmer 2005: 166) failed.

As a counterweight to "nationalised" social sciences, I would therefore like to imagine an academic field freed from national chauvinisms where researchers can, freely and independently of their nationality and mother tongue, suggest new methods that might be transposable to other subjects. As this article suggests, relatively unexplored avenues still remain, such as methods relating to the "a posteriori sociology of indigenous experience" to which Chinese researchers such as Liu Xiaomeng 刘小萌, a specialist in rusticated youth who was one himself, wish to make a contribution.

It is not my intention here to defend the supposed "imperialism" of the so-called "Western" sciences and even less to suggest that mainland China can be studied in the same way as the Argonauts of the Western Pacific (Malinowski 1989). I would simply like to advocate several additional precautions and wider epistemological, empirically-based discussions on the subject of a debate on "Chinese social sciences," which has been undermined for more than a century by nationalism, reifications such as "West" and "China," and/or by ambitious and in some respects performative discourse (Boatca 2012).

By using the tools and concepts of the social sciences to analyse the social sciences as Pierre Bourdieu (1984), for example, suggested, researchers would certainly have more elements at their disposal for separating epistemologically fertile thinking from "speeding" ("excès de vitesse," Passeron 1987) and other symbolic shows of strength. ${ }^{(6)}$

\section{Translated by Elizabeth Guill.}

I Aurélien Boucher is a Lecturer in the Department of Humanities and Social Sciences at the Chinese University of Hong Kong (Shenzhen).

School of Humanities and Social Sciences, the Chinese University of Hong-Kong (Shenzhen), 2001 Longxiang Avenue, Longgang District, 518100, Shenzhen (aurelienboucher@cuhk.edu.cn).

Manuscript received on 1 December 2017. Accepted on 20 August 2018.

6. Bourdieu, speaking on this subject in his lectures at the Collège de France, stated, "One of the challenges of the symbolic struggles that I am discussing today is to manipulate the principles of vision and division, to play with the categories of perception of the social world. To say that something is post-, ante-, neo-, or paleo (...) is, in reality, to constitute in a certain manner, and this act of constitution, in the traditional and judicial philosophical sense, will have the force, the weight of the authority of the constituant act (...). In my opinion, people who can say 'post' or 'ante' are not sociologists" (Bourdieu 2016: loc1734). 


\section{References}

ARENDT, Hannah. 1985. The Origins of Totalitarianism. San Diego, New York, London: Harvest Book.

ATTANÉ, Isabelle. 2011. Au pays des enfants rares. Le Chine vers la catastrophe démographique (In the country of rare children. China heading for demographic catastrophe). Paris: Fayard.

BAJOS N., MOREAU C., LERIDON H., and FERRAND M. 2004. "Pourquoi le nombre d'avortements n'a-t-il pas baissé en France depuis 30 ans?" (Why has the number of abortions in France not fallen in 30 years?). Population et Sociétés 407: 1-4.

BAYART, Jean François. 2010. Les études postcoloniales, un carnaval académique (Post-colonial studies, an academic carnaval). Paris: Karthala.

BEAUD, Stéphane, and Florence WEBER. 2003. Guide de l'enquête de terrain (Guide to studies in the field). Paris: La découverte.

BIANCO, Lucien. 2014. La récidive: révolution russe, révolution chinoise (Recurrence: Russian revolution, Chinese revolution). Paris: Gallimard.

BOATCA, Manuela. 2012. Review of Laurence Roulleau Berger "Désoccidentaliser la sociologie. L'Europe au mirroir de la Chine" (De-westernising sociology. Europe in the mirror of China). European Societies 14(5): 784-6.

BOUCHER, Aurélien. 2017. "Les archives de la République Populaire de Chine Raisonner sur et raisonner avec" (The archives of the People's Republic of China. Reasoning on and reasoning with). Histoire Sociale 101: 139-59.

BOUCHER, Aurélien. 2018. "Review of Laurence Roulleau Berger, PostWestern Revolution in Sociology." Theory Culture and Society, https://www.theoryculturesociety.org/review-of-laurence-roulleau-bergerpost-western-revolution-in-sociology/ (accessed on 10 November 2017).

BOURDIEU, Pierre. 1984. Homo Academicus. Paris: Seuil.

BOURDIEU, Pierre. 1994. Raisons pratiques. Sur la théorie de l'action (Practical reason. On the theory of action). Paris: Seuil.

BOURDIEU, Pierre. 2012. Sur L'État, cours au collège de France 1989-1992 (On the State, lectures at the Collège de France). Paris: Seuil.

BOURDIEU, Pierre. 2016. Sociologie Générale, Volume 2: Cours au collège de France 1983-1986 (General sociology, volume 2: lectures given at the Collège de France). Paris: Raison d'Agir/Seuil.

CAO Shuji 曹树基. 2005. 大饥荒 - 1959-1961的中国人口 (Da jihuang 1959-1961 de Zhongguo renkou, The Great Famine: the Chinese population between 1959 and 1961). Hong Kong:Xianggang shidai guoji chuban.

CAO Shuji 曹树基. 2005. "Deaths in the Chinese Population 1959-1961 and Contributing Factors." Chinese Journal of Population Science 2015(1): 16-30.

CHAPOULIE, François. 2001. La tradition sociologique de Chicago: 18621961 (The Chicago tradition of sociology: 1862-1961). Paris: Seuil.

CHING, May Bo. 2017. "Chinese History in China: The State of the Field (1980s-2010s)." In Michael Szonyi (ed.), A Companion to Chinese History. Hoboken, New Jersey: Wiley-Blackwell. 28-43.

CHUN Shihua 淳世华. 2014. “彭水县大饥荒人口非正常死亡报告” (Penshui xian Da jihuang renkou fei zhengchang siwang baogao, Report on unnatural deaths during the Great Famine in the canton of Pengshui). Yanhuang Chunqiu 270(2014/9): 30-8.

DAVIES, Robert W. 2009. The Year of Hunger: Soviet Agriculture 19311933. Basingstoke: Palgrave Macmillan.

DE BARROS, Françoise. 2008. "Les acteurs municipaux et 'leurs' étrangers (1919-1984): gains et contraintes d'un détour communal pour l'analyse d'un travail de catégorisation étatique" (Municipal players and "their" foreigners 1919-1984: gains and constraints of a communal detour in the analysis of state categorisation). Genèses 72(3): 42-62.

DIKÖTTER, Frank. 2010. Mao's Great Famine. London: Bloomsbury.
DOMENACH, Jean-Luc. 2004. "Chine: Les balbutiements de l'histoire" (China: the beginnings of history). Critique internationale 24(2004): 81-103.

DURKHEIM, Émile. 2013. Les formes élémentaires de la vie religieuse (The elementary forms of religious life). Paris: PUF.

DURKHEIM, Émile. 2013. De la division du travail social (The division of labour in society). Paris: PUF.

FEI Xiaotong 费孝通. 2006. 乡土中国 (Xiangtu Zhongguo, From the Soil). Shanghai: Shanghai renmin chubanshe.

FITZPATRICK, Sheila. 1986. "New Perspectives on Stalinism." The Russian Review 45: 357-73.

FORSTER, Keith. 1999. "Localism, Central Policy and the Provincial Purge in Zhejiang 1957-1958." In Timothy Cheek et al. (eds.), New Perspectives in State Socialism in China. London: Routledge.

GE, Zhaoguang. 2014. An Intellectual History of China. Leiden and Boston: Brill.

GENET, Jean-Philippe. 1997. "La genèse de l'État moderne" (The genesis of the modern state)." Actes de la recherche en sciences sociales 118: 3-18.

GETTY, John Archibald. 1985. The Origins of the Great Purges, The Soviet Party Reconsidered 1933-1938. Cambridge: Cambridge University Press.

GHOSH, Arunabh. 2014. "Making it Count: Statistics and State-Society Relations in the Early People's Republic of China 1949-1959." Doctoral Thesis, Columbia.

GUAN Hong 关鸿. 1986. 兵乓启示录: 庄则栋在《文革》中 (Pingpang qishi lu: Zhuang Zedong zai 'wenge' zhong, New revelations on table tennis Zhuang Zedong in the Cultural Revolution). Hangzhou: Jiangsu wenyi chubanshe.

HE Zhiyi 何志毅. 2009. 冠军的尊严 (Guanjun de Zunyan, The honour of a champion). Guangzhou: Guangdong renmin chubanshe.

HEIMER, Maria, and Stig THØGERSEN (eds.). 2006. Doing Fieldwork in China. Copenhagen: NIAS.

KERSHAW, lan, and Moshe LEWIN. 1997. Stalinism and Nazism: Dictatorships in Comparison. Cambridge: Cambridge University Press.

KRAGH, Martin, and Stefan HEDLUND. 2015. "Researching Soviet Archives: An Introduction." The Russian Review 74: 373-6.

KRAUS, Charles. 2016. "Researching the History of the People's Republic of China." CWIHP Working Paper 79. April 2016. https://www.wilsoncenter.org/publication/researching-the-history-the-peoples-republic-china (accessed on 10 November 2017).

LAURENT, Sébastien (ed.). 2003. Archives secrètes, secrets d'archives? Historiens et archivistes face aux archives sensible (Secret archives, secrets of the archives? Historians and archivists confronted with sensitive archives). Paris: CNRS Edition.

LEW, Roland. 2009. "Le socialisme réel: une nouvelle donne" (Real socialism: a new deal). L'homme et la société 172-173: 127-42.

LEYS, Simon. 1998. Essais sur la chine, Les habits neufs du président Mao (Essays on China, the chairman's new clothes). Paris: Robert Laffont.

LI Lingxiu 李玲修. 2002. 体育之子荣高棠 (Tiyu zhi zi Rong Gaotang, The son of sport Rong Gaotang). Beijing: Xinhua chubanshe.

LI Zongke 李宗克 and Cao Jinqing 曹锦清. 2013. “社会科学本土化的理论 内涵" (Shehui kexue bentuhua de lilun neihan, The theoretical content of localised social sciences). Huadong ligong daxue xuebao 2: 1-9.

LIEBERTHAL, Kenneth, and David M. LAMPTON. 1992. Bureaucracy, Politics, and Decision Making in Post-Mao China. Berkeley: University of California Press.

LIPSKY, Michael. 1980. Street-level Bureaucracy. Dilemmas of the Individual in Public Services. New York: Russell Sage Foundation. 
LIU Bingrong 刘秉荣. 2007. 建国后的贺龙 (Jianguo hou de He Long, He Long after the establishment of the People's Republic of China). Peking: Dangdai Zhongguo chubanshe.

LOIRAND, Gildas. 2006. "Parachutisme. La célébration du danger" (Parachutism. The celebration of danger). Ethnologie Française 36(4): 625-34.

MACFARQUHAR, Roderick, and Michael SCHOENHALS. 2006. Mao's Last Revolution. Cambridge, Massachussets: Harvard University Press.

MALINOWSKI, Bronlislav. 1989. Les argonautes du Pacifique occidental (The argonauts of the Western Pacific). Paris: Gallimard.

MCDERMOTT, Kevin. 2004. "Archives, Power and the 'Cultural Turn': Reflections on Stalin and Stalinism." Totalitarian Movements and Political Religions 5(1): 5-24.

MCNEAL, Robert H. 1971. "The Decisions of the CPSU and the Great Purge." Soviet Studies 23(2): 177-85.

MCNEAL, Robert H. 1972. Guide to the Decisions of the Communist Party of the Soviet Union 1917-1967. Toronto: University of Toronto Press.

MCNEAL, Robert H. 1975. Resolutions and Decisions of the CPSU. Toronto: University of Toronto Press.

MERLE, Isabelle. 2004. "Les Subaltern studies, Retour sur les principes fondateurs d'un projet historiographique de l'Inde colonial" (The subaltern studies. Return to the founding principles of a historiographical project of Colonial India). Genèses 56(2004/3): 131-47.

MERLE, Aurore. 2007. "De la reconstruction de la discipline à l'interrogation sur la transition: la sociologie chinoise à l'épreuve du temps" (From the reconstruction of the discipline to questions on the transition). Cahier internationaux de Sociologie 122(2007/1): 31-52.

MESPOULET, Martine. 2001. Statistique et révolution en Russie: Un compromis impossible (Statistics and revolution in Russia: an impossible compromise 1880-1930). Rennes: Presses universitaires de Rennes.

MESPOULET, Martine. 2003. L'anarchie bureaucratique: Statistique and pouvoir sous Staline (Bureaucratic anarchy: statistics and power under Stalin). Paris: La Découverte.

MESPOULET, Martine. 2008. Construire le socialisme par les chiffres. Enquêtes and recensements en URSS de 1917 à 1991 (Constructing socialism through figures. Surveys and censuses in the USSR from 1917 to 1991). Paris: INED.

MOSELEY, Eva. 1987. "Visting Archives in China." American Archivist 50(1): 137-41.

MOSS, William. 1982. "Archives in the People's Republic of China." American Archivist 45(4): 385-409.

PALMER, David A. 2005. La fièvre du Qigong (Qigong fever). Paris: EHESS.

PASSERON, Jean-Claude. 1987. "Attention aux excès de vitesse: le nouveau comme concept sociologique" (Beware of speeding: the new as sociological concept). Esprit 125(4): 129-34.

PASSERON, Jean-Claude. 1991. Le raisonnement sociologique. L'espace non-poppérien du raisonnement naturel (Sociological reasoning. A nonpopperian space of argumentation). Paris: Nathan.

PETO, Andrea. 2009. "L'ouverture des archives d'une police politique communiste: Le cas Tchèque, de Zdena Salivarova à Milan Kundera" (Opening the archives of a communist political police: the Czech case, from Zdena Salivarova to Milan Kundera). In Sonia Combe (ed.), Archives et histoire dans les sociétés Post-communistes (Archives and history in post-communist societies). Paris: La Découverte. 203-25.

PREZIOSIO, Stéfanie (ed.). 2008. Le totalitarisme en question (Totalitarianism in question). Paris: L'Harmattan.

RALEIGH, Donald J. 2002. "Doing Soviet History: The Impact of Archive Revolution." The Russian Review 61(1): 16-24.
REINBOTHE, Roswitha. 2010. "L'exclusion des scientifiques allemands and de la langue allemande des congrès scientifiques internationaux après la Première Guerre mondiale (The exclusion of German scientists and the German language from international scientific conferences after the First World War). Revue Germanique Internationale 12: 193-208.

REVEL, Jacques (ed.). 1996. Jeux d'échelles. La micro-analyse à l'expérience (The play of scales. The micro-analysis experiment). Paris: Gallimard-Le Seuil. ROCCA, Jean-Louis (ed.). 2008. La société chinoise vue par ses sociologues (Chinese society seen through its sociologists). Paris: Sciences Po.

ROULLEAU-BERGER, Laurence. 2011. Désoccidentaliser les social sciences, L'Occident au miroir de la Chine (De-westernising the social sciences. The West in the mirror of China). Paris: Édition de l'Aube.

ROULLEAU-BERGER, Laurence. 2016. Post Western Revolution in Sociology. Leiden: Brill.

ROWELL, Jay. 2002. "Le pouvoir périphérique et le centralisme démocratique en RDA" (Peripheral power and democratic centralism in the GDR). Revue d'histoire moderne et contemporaine 49: 102-24.

SAÏD, Edward. 2003. L'orientalisme (Orientalism). Paris: Seuil.

SHIYing 石英. 2013. “质性研究与社会学的中国化” (Zhixing yanjiu yu shehuixue de zhongguohua, Quantitative studies and the Sinicisation of sociology). Renwen zazhi 4: 101-7.

SPIRE, Alexis. 2007. Sociologie historique des pratiques administratives à l'égard des étrangers en France (Sociological history of administrative practices with regard to foreigners in France). Doctoral Thesis, University of Nantes.

SUN Jingsheng 孙经生. 2011. “关于我国二十世纪60年代人口变动问题的 研究” (Guanyu wo guo 20 shiji 60 niandai renkou biandong wenti de yanjiu, Concerning research into the subject of changes in the population of our country in the 1960s). Makesi zhuyi yanjiu 6: 62-75.

TEIWES, Frederick C. 1966. "The Purge of provincial Leaders 1957-1958." China Quarterly 27: 14-32.

VEYNE, Paul. 1983. Les Grecs ont-ils cru en leurs mythes (Did the Greeks believe in their Myths?). Paris: Seuil.

WANG Dinghua 王鼎华. 2008. 王猛将军体育缘 (Wang Meng Jiangjun tiyu yuan, The sporting cause of general Wang Meng). Beijing: Renmin tiyu chubanshe.

WANG Ning 王宁. 2017. “社会学本土化议题, 争辩, 症结与出路” (Shehui xue bentuhua yiti: zhengbian, zhengjie yu chulu, Indigenisation of sociology in China: debates, core problems and the way forward). Shehuixue yanjiu 5: 15-38.

WEBER, Max. 1995. Economie et Société, les catégories de la sociologie (Economy and society, the categories of sociology). Paris: Plon.

XING, Long and MA Wenqiang. 2008. "Rural Grassroots Files from the collectivization Era: Archives of the social history research center of Shanxi university." Modern China 34(3): 372-95.

XU Yinsheng 徐寅生. 1995. 我与乒乓球：徐寅生自传 (Wo yu pingpang qiu: Xu Yinsheng Zizhuan, Table tennis and me: the autobiography of Xu Yinsheng). Beijing: Zhongguo shehui kexue chubanshe.

YANG Jisheng. 2013. Tombstone: The Great Chinese Famine, 1958-1962. New York: Farrar, Straus and Giroux.

YANG Jisheng 杨继绳. 2013. “驳'饿死三千万是谣言'再答孙经生对“墓碑”的 指责" (Bo 'Esi san qianwan shi yaoyan' zai da Sun Jingsheng dui 'mubei' de zhize, The death of thirty million people is a rumour. New answer to the critique of Tombstone by Sun Jingsheng). Yanhuang Chunqiu 261: 75-81.

YANG Jisheng 杨继绳. 2016. 天地翻覆 : 中国文化大革命史 (Tiandi fanfu: Zhongguo wenhua da geming shi, The world turned upside down: history of the Cultural Revolution). Hong Kong: Cosmos Book. 